\title{
LA-SUB- $98-36$
}

\section{R\&D 100 MARKET ASSESSMENT}

Title Of Invention:

Inventors:
Microwave Solidification System

Ravi Varma

Marketing Account Manager: Melissa Miller (via Quatro - Mike Dinall RECEIVED

\section{APR 121999}

\section{APPLICATIONS}

- Principal applications

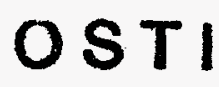

The microwave solidification system can be used for treating a variety of waste materials. The principal application is for treating solid and liquid nuclear waste in the form of residue oxides and salts, sludges, contaminated materials used in processing or handling nuclear materials and combustion residues.

- Other applications

The microwave solidification system can also be used to treat organic waste products such as: food packaging solidification; grease and oil removal from waste streams and sterilization of infectious medical wastes. The system can also be used to synthesize ceramics.

- Future applications

Possible future applications may include treatment of asphalt paving material, polymer processing, inorganic waste treatment, semiconductor doping and processing of pharmaceutical capsules.

- List of competing technologies (See attached Comparison Matrix)

There are several technologies for solidification of nuclear waste, such as plasma heating, resistance heating, arc-furances and microwaves. Similarly, treatment of organic wastes presently use microwaves systems. The provided comparison matrix compares some alternative technologies with the multimode LANL microwave system.

- Advantages of LANL invention over competing technologies (for each application)

The distinguishing feature of the LANL microwave system is that uniform heating is acheived throughout the waste volume which results in more waste containment. Uniform heating is acheived by creating two additional microwave modes in the heating cavity and use of a waste perifery "sleeve" which is also part of the invention. For infectious medical waste sterilization, the LANL microwave system achieves 100-percent sterilization, current thermal treatment complete sterilization 


\section{DISCLAIMER}

Portions of this document may be illegible in electronic image products. Images are produced from the best available original document. 
is not achieved. The ceramics fabrication application, due to the uniform heating capability, would permit larger sized ceramics to be produced.

- Market Analysis (for each application, given adequate specific information)

- Size: The principal market for the microwave solidification system is the nuclear power industry. Total revenues for this industry ${ }^{1}$ in 1993 was $\$ 39 B$ (50 states). The cost for management of nuclear waste products is approximately $\$ 100 \mathrm{M}$ annually. The uniform heating capability of the microwave solidification system would be vying for some portion this market.

- Key Companies: Westinghouse, Chem-Nuclear Systems, EG\&G, Exxon Nuclear, and Canberra Industries are candidate companies for either using or manufacturing the microwave solidification system. Each of these companies have operated, designed and produced nuclear waste containment and solidification systems and equipment for over thirty years; and have worked with government laboratories and commercial and utilities in the nuclear power industry.

- Relevant Industry Trends: Nuclear waste containment costs represent a financial burden to the industry and government, which continues to provide R\&D funding for waste containment. 2

- Relevant Regulations: None identified.

- Potential Barriers: Other multimodal microwave heating cavity systems are in use. Invention test data hasn't been obtained.

- Foreign Market Information: Is available, but requires additional research.

\footnotetext{
1Standard and Poor's Industry Survey, Oct 95.

2Market Share Reporter.
} 


\section{Microwave Solidification System Comparison Matrix}

\begin{tabular}{|c|c|c|c|}
\hline Parameter & $\begin{array}{l}\text { LANL's Microwave } \\
\text { Solidification System }\end{array}$ & $\begin{array}{l}\text { Other Microwave Waste } \\
\text { Processing Systems }\end{array}$ & $\begin{array}{l}\text { Conventional } \\
\text { Waste Treatment }\end{array}$ \\
\hline Uniform Waste Heating & $\begin{array}{l}\text { multimodal and perifery } \\
\text { sleeve allow uniforming } \\
\text { heating }\end{array}$ & $\begin{array}{l}\text { existing systems have mode } \\
\text { "stirring" which allow uniform } \\
\text { heating }\end{array}$ & $\begin{array}{l}\text { given sufficient time } \\
\text { and temperature, } \\
\text { uniform heating is } \\
\text { acheived }\end{array}$ \\
\hline Safety & $\begin{array}{l}\text { less risk of possible } \\
\text { radiation exposure }\end{array}$ & $\begin{array}{l}\text { also safer with reqard to } \\
\text { radiation exposure }\end{array}$ & $\begin{array}{l}\text { Generally more of a } \\
\text { safety concern }\end{array}$ \\
\hline Operation & $\begin{array}{l}\text { is automated and } \\
\text { transportable }\end{array}$ & $\begin{array}{l}\text { other microwave systems are } \\
\text { probably automated and } \\
\text { mobile }\end{array}$ & $\begin{array}{l}\text { operation requires } \\
\text { personnel, generally } \\
\text { not mobile }\end{array}$ \\
\hline Cost & $\begin{array}{l}\text { estimated to be } 16 \% \\
\text { cheaper than most } \\
\text { conventional treatments }\end{array}$ & $\begin{array}{l}\text { other microwave systems are } \\
\text { also more cost effective than } \\
\text { conventional treatments }\end{array}$ & $\begin{array}{l}\text { typically more } \\
\text { expensive due to } \\
\text { inefficient heat } \\
\text { conversion process }\end{array}$ \\
\hline
\end{tabular}

\footnotetext{
${ }^{3}$ Includes oil/gas based furnance heating, RF Induction Heating, and Electrical (Resistive) Heating.
} 